\title{
Pengembangan Modul Pembelajaran Matematika dengan Pendekatan Matematika Realistik
}

\author{
Zahra Nur Fitriyana ${ }^{1 *}$, Mailizar $^{2}$, \& Seruni $^{3}$ \\ 1, 2, 3. Universitas Indraprasta PGRI, Jakarta, Indonesia
}

\section{INFO ARTICLES}

Article History:

Received: 29-06-2021

Revised: 30-06-2021

Approved: 30-06-2021

Publish Online: 30-06-2021

\section{KeyWords:}

Module; Mathematics; Realistic Mathematics Approach;

\section{This article is licensed} under a Creative Commons AttributionShareAlike 4.0 International License.

Correspondence Address: J1. Raya Tengah No. 80, Pasar Rebo, Jakarta Timur. Indonesia; e-mail: zahranajah61@gmail.com

How to Cite (APA $6^{\text {th }}$ Style): Fitriyana, Z.N., Mailizar, M., \& Seruni, S. (2021). Pengembangan Modul Pembelajaran Matematika dengan Pendekatan Matematika Realistik. JKPM (Jurnal Kajian Pendidikan Matematika), 6(2): 279-292

Copyright: 2021 Zahra Nur Fitriyana, Mailizar Mailizar, Seruni Seruni

Competing Interests Disclosures: The authors declare that they have no significant competing financial, professional or personal interests that might have influenced the performance or presentation of the work described in this manuscript. 


\section{PENDAHULUAN}

Pendidikan merupakan salah satu upaya untuk meningkatkan dan mengembangkan sumber daya manusia yang berkualitas. Salah satu upaya yang dapat dilakukan untuk meningkatkan sumber daya manusia adalah meningkatkan kualitas pendidikan yang berfokus pada pengembangan kemampuan berpikir siswa. Sementara itu pemikiran yang kritis, kreatif, sistematis dan logis dapat dikembangkan melalui pendidikan matematika. Matematika merupakan ilmu yang mampu melatih daya analisis dan logika para siswa dengan pola dan aturan-aturan yang didefinisikan secara cermat dan akurat sehingga dapat bermanfaat bagi siswa dalam menyelesaikan permasalahan. Mulyono (2003:252) menyatakan bahwa matematika adalah suatu cara untuk menemukan jawaban terhadap masalah yang dihadapi manusia, suatu cara menggunakan informasi, menggunakan pengetahuan tentang menghitung dan yang paling penting adalah memikirkan dalam diri manusia itu dalam melihat dan menggunakan hubungan-hubungan, sehingga dapat diartikan bahwa dengan belajar matematika kita dapat menemukan jawaban atas masalah yang sedang dihadapi yang berhubungan dengan matematika. Belajar matematika juga memerlukan penalaran yang baik. Seperti yang diungkapkan Tinggih (dalam Erman, 2003:18), matematika berarti ilmu pengetahuan yang diperoleh dengan bernalar. Hal ini dimaksudkan bukan berarti ilmu lain diperoleh tidak melalui penalaran, akan tetapi dalam matematikan lebih menekankan aktivitas dalam dunia rasio (penalaran), sedangkan dalam ilmu lain lebih menekankan hasil observasi atau eksperimen dihasil penalaran.

Berdasarkan hasil wawancara yang dilakukan di SMP 90 Jakarta, fokus pembelajaran matematika di sekolah yang terjadi secara umum masih cenderung pada ketercapaian target materi menurut kurikulum atau buku ajar, bukan pada pemahaman materi yang dipelajari. Hal ini mengakibatkan siswa cenderung hanya menghafal konsep-konsep matematika, tanpa memahami maksud dan isinya. Sistem pembelajaran yang diterapkan tanpa menyarankan keterkaitan maupun implementasinya dalam kehidupan sehari-hari menyebabkan pembelajaran menjadi kurang bermakna. Hal tersebut dikarenakan guru dalam pembelajarannya di kelas tidak mengaitkan dengan skema yang telah dimiliki oleh siswa dan siswa kurang diberikan kesempatan untuk menemukan kembali serta mengkonstruksi sendiri ide-ide matematika, sehingga siswa masih belum terlibat aktif dalam kegiatan pembelajaran matematika.

Faktor lain yang diduga sebagai masalah dalam proses pembelajaran matematika, menurut para siswa terdapat beberapa materi pembelajaran yang sering kali sulit dirasa siswa untuk dipahami ataupun dijelaskan. Kesulitan atau masalah tersebut dapat terjadi karena salah satu karakteristik matematika yang mempunyai objek bersifat abstrak. Sifat ini pula merupakan salah satu hal yang menyebabkan siswa mengalami kesulitan dalam mempelajari materi pembelajaran matematika karena kurangnya pemahaman siswa untuk menyelesaikan hal-hal yang bersifat abstrak tersebut. Hal ini disebabkan siswa belum dapat menggunakan objek-objek yang ada dalam kehidupan sehari-hari dengan suatu permasalahan. Oleh sebab itu, dalam proses pembelajaran diperlukan suatu pendekatan yang dapat membantu atau memfasilitasi siswa untuk menghubungkan materi pelajaran yang sekiranya masih abstrak dengan hal-hal nyata dalam kehidupan sehari-hari. Jika siswa mendapat kemudahan dalam memahami konsep-konsep matematika, maka siswa akan tertarik untuk mempelajari dan mendapat makna dalam proses pembelajarannya. Oleh karena itu diperlukan suatu media pembelajaran yang dapat memfasilitasi siswa dalam memahami materimateri matematika yang dipelajari dengan situasi dunia nyata.

Berdasarkan hasil wawancara lisan dengan guru mata pelajaran matematika di SMP Negeri 90 Jakarta dan siswa yang telah mempelajari mata pelajaran matematika di kelas VII, diperoleh informasi bahwa kegiatan pembelajaran matematika di SMPN 90 Jakarta sampai saat ini belum menggunakan modul, melainkan masih menggunakan buku-buku atau bahan ajar cetak konvensional. Pendidik hanya menggunakan sebuah buku sebagai satu-satunya bahan ajar. Materi yang disajikan di dalam bahan ajar 
cetak tersebut banyak yang bersifat abstrak dan rumit sehingga siswa enggan untuk membacanya apalagi mempelajarinya. Dalam belajar matematika, Nasution (2010:204) mengemukakan bahwa pendidik mengetahui bahwa para peserta didik menunjukkan perbedaan dalam cara-cara belajar. Pengajaran klasikal yang menggunakan proses belajar mengajar yang sama bagi semua peserta didik tidak akan sesuai bagi kebutuhan dan kepribadian setiap peserta didik. Oleh karena itu diperlukan suatu media pembelajaran yang dapat membantu siswa belajar secara mandiri. Salah satu media pembelajaran yang dapat memfasilitasi belajar siswa adalah modul. Prastowo (2013:106) mengatakan modul adalah sebuah bahan ajar yang disusun secara sistematis dengan bahasa yang mudah dipahami oleh siswa sesuai tingkat pengetahuan dan usia mereka, agar mereka dapat belajar sendiri dengan bantuan dan bimbingan yang minimal dari pendidik. Nasution (2005:205) mengungkapkan bahwa modul merupakan suatu unit lengkap yang berdiri sendiri dan terdiri atas suatu rangkaian kegiatan belajar yang disusun untuk membantu siswa belajar mandiri dalam mencapai sejumlah tujuan yang dirumuskan secara khusus dan jelas. Berdasarkan teori diatas maka dapat disimpulkan modul merupakan media pembelajaran berbentuk cetak yang menyajikan materi pembelajaran sebagai bahan ajar mandiri bagi siswa. Dengan adanya pembaharuan kurikulum, guru dituntut agar lebih kreatif dan inovatif dalam menyediakan maupun menyajikan perangkat yang dibutuhkan dalam proses pembelajaran. Oleh karena itu, pengembangan media pembelajaran berupa modul dibutuhkan dalam kegiatan pembelajaran. Bahan ajar dan model pembelajaran yang sesuai dengan kondisi sekolah dan karakter siswa akan meningkatkan keaktifan, kemandirian dan keterampilan berpikir siswa serta mendukung tercapainya tujuan pembelajaran.

Pembelajaran dengan menggunakan pendekatan Pembelajaran Matematika Realistik pada dasarnya adalah pemanfaatan realitas dan lingkungan yang dipahami siswa untuk memperlancar proses pembelajaran matematika, sehingga mencapai tujuan pendidikan matematika secara lebih baik. Yang dimaksud dengan realita yaitu hal-hal yang nyata atau kongkret yang dapat diamati atau dipahami siswalewat membayangkan, sedangkan yang dimaksud dengan lingkungan adalah lingkungan tempat siswaberada baik lingkungan sekolah, keluarga ataupun masyarakat yang dapat dipahami siswa. Sovianawati (2011:81) mengemukakan bahwa lingkungan dalam hal ini disebut juga kehidupan seharihari. Sedangkan Murdani, Johar, \& Turmudi, (2013) mengatakan pembelajaran matematika realistik dilakukan melalui lima langkah yaitu: memahami masalah realistik, menyelesaikan masalah realistik, membandingkan atau mendiskusikan jawaban dalam kelompok, diskusi kelas dan menyimpulkan. Dengan diterapkannya penggunaan modul, pembelajaran lebih terencana dan menghasilkan hasil yang jelas. Modul dengan pendekatan matematika realistik dipandang dapat mengaktifkan siswa dalam proses pembelajaran dengan pengetahuan awal yang telah dimiliki, mengaitkan pembelajaran dengan situasi lingkungan siswa, memotivasi siswa dengan menyediakan kegiatan atau tugas matematika yang berhubungan dengan kehidupan sehari-hari. Adanya modul dengan pendekatan matematika realistik diharapkan dapat membentuk sikap positif siswa terhadap materi pelajaran, khususnya matematika. Dengan sikap positif dalam diri siswa akan membuat siswa memiliki motivasi dan minat dalam belajar sertadapat dengan mudah memulai pembelajaran dengan persoalan dalam kehidupan nyata atau realistik sehingga siswa dapat lebih mudah menyerap materi yang dipelajari dan meningkatkan pemahaman konsep matematika.

Dalam penelitian ini peneliti ingin mengembangkan modul pembelajaran matematika dengan pendekatan matematika realistik dan akan melakukan uji kelayakan dengan uji para ahli, sehingga nantinya siswa dapat memiliki sumber belajar yang dapat meningkatkan kemandirian dan keterampilan berpikir dalam pemahaman konsep matematika sehingga dapat dijadikan bekal dalam memecahkan berbagai masalah yang berkaitan dalam kehidupan sehari-hari dan guru bisa menjadikan modul ini sebagai masukan dan sumbangan pemikiran dalam mengembangkan bahan ajar berupa modul dengan pendekatan matematika realistik sebagai upaya meningkatkan pemahaman konsep matematika. 


\section{METODE}

Jenis penelitian yang digunakan pada penelitian ini adalah penelitian pengembangan (Research and Development). Penelitian ini berfokus pada pengembangan modul dengan pendekatan maematika realistik. Model desaign penelitian pengembangan ini menggunakan penelitian $\mathrm{R}$ \& $\mathrm{D}$ yaitu melalui model desain pembelajaran ADDIE (Analysis-Design-Develop-Implement-Evaluate) yang dipadukan menurut langkahlangkah penelitian pengembangan yang direkomendasikan oleh Borg dan Gall pada tahun 1989 dengan dasar pertimbangan bahwa model tersebut cocok untuk mengembangkan produk model instruksional/pembelajaran yang tepat sasaran, efektif dan dinamis dan sangat membantu dalam pengembangan pembelajaran bagi guru. Desain penelitian ini diperlihatkan dalam Gambar 1. (Tegeh, \& Sukmana, 2018)

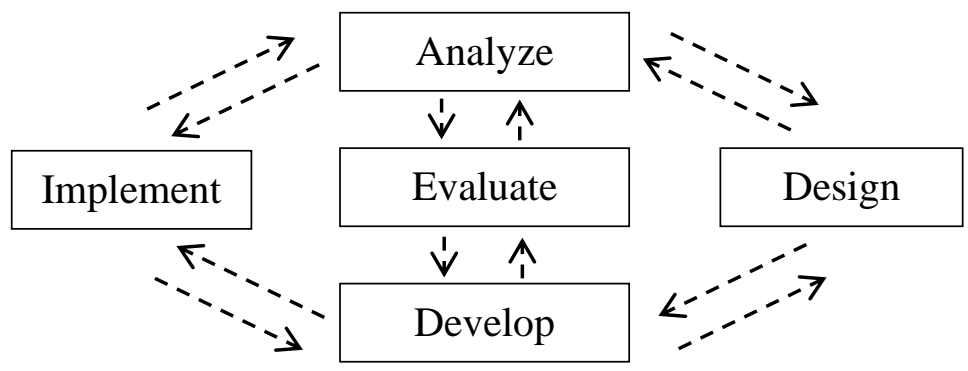

\section{Gambar 1. Desain Model Penelitian Pengembangan ADDIE}

Pada tahap analyze dilakukan identifikasi masalah (kebutuhan) dan menganalisis kebutuhan tugas (task analyze). Tahap Design ini membuat rancangan bangunan diatas kertas terlebih dahulu sebelum menyusun modul. Tahap Develop ini merancang produk sesuai dengan desaign yang sudah dirancang. Tahap Implement ini akan dilaksanakan uji pakar untuk mendapatkan saran, masukkan, dan penilaian yang akan dilakukan kepada ahli materi, ahli media dan ahli bahasa. Tahap Evaluate melihat keberhasilan sistem pembelajaran yang sedang dibangun. Tahap evaluasi bisa dilakukan pada setiap empat tahap diatas yang disebut evaluasi formatif, karena tujuannya adalah untuk revisi.

HASIL

1. Analyze

Tabel 1. Hasil Wawancara Kepada Guru Mata Pelajaran Matematika

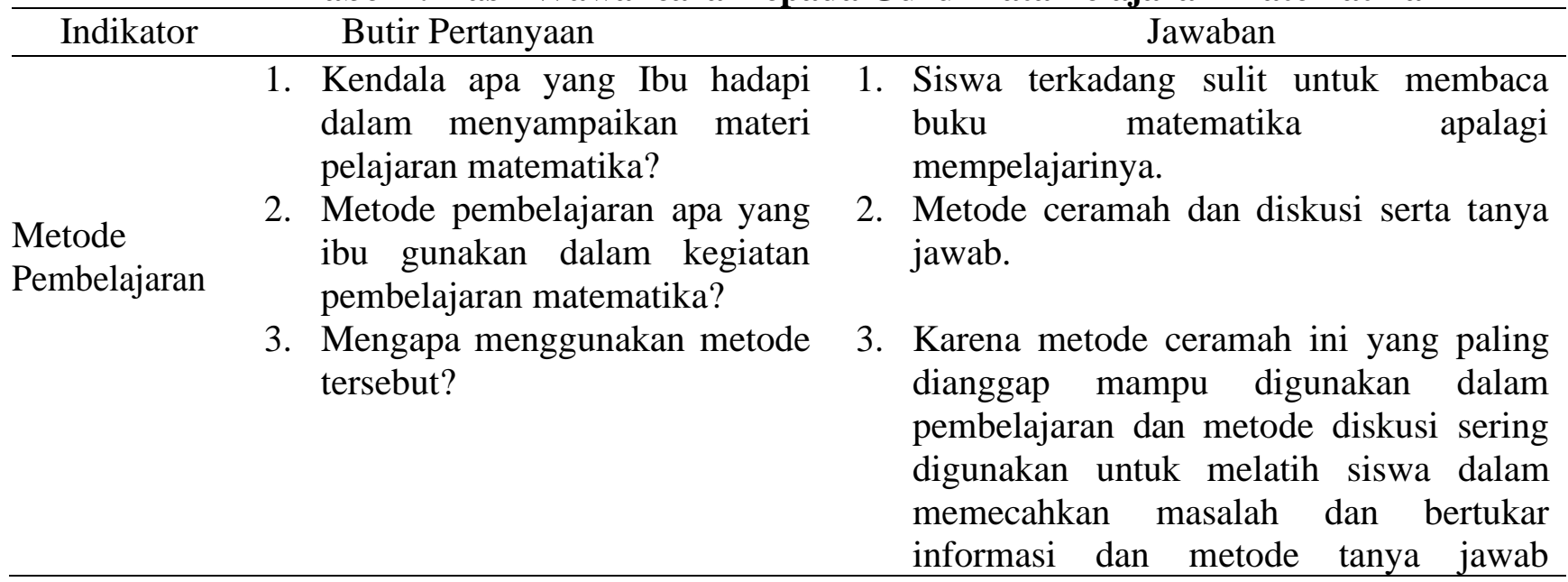




\begin{tabular}{|c|c|c|}
\hline Indikator & Butir Pertanyaan & Jawaban \\
\hline & & $\begin{array}{l}\text { digunankan untuk } \\
\text { kemampuan siswa. }\end{array}$ \\
\hline & $\begin{array}{l}\text { 4. Bahan ajar apa saja yang Ibu } \\
\text { gunakan dalam pembelajaran? }\end{array}$ & $\begin{array}{l}\text { 4. Yang paling sering digunakan adalah } \\
\text { buku paket atau bahan ajar cetak } \\
\text { konvensional. }\end{array}$ \\
\hline & $\begin{array}{l}\text { Bahan ajar seperti apa saja yang } \\
\text { sesuai digunakan oleh siswa } \\
\text { kelas VII? }\end{array}$ & $\begin{array}{l}\text { 5. Bahan ajar yang mudah digunakan oleh } \\
\text { peserta didik tentunya, menarik tetapi } \\
\text { tetapmempertahankan isi yang relevan } \\
\text { dengan materi dan harus bisa } \\
\text { menyesuaikan dengan kondisi siswa. }\end{array}$ \\
\hline \multirow[t]{2}{*}{$\begin{array}{l}\text { Harapan } \\
\text { mengenai } \\
\text { pengembangan } \\
\text { bahan ajar }\end{array}$} & $\begin{array}{l}\text { 6. Bagaimana pendapat Ibu } \\
\text { mengenai pengembangan bahan } \\
\text { ajar yang saya buat? }\end{array}$ & $\begin{array}{l}\text { 6. Sangat baik, itu untuk membantu guru } \\
\text { mencapai tujuan pembelajaran yang } \\
\text { efektif dan dapat meningkatkan } \\
\text { kemandirian siswa juga. }\end{array}$ \\
\hline & $\begin{array}{l}\text { 7. Apa kekurangan maupun } \\
\text { kendala } \\
\text { pemanfaatan bahan ajar ini } \\
\text { dalam } \\
\text { Matematika? }\end{array}$ & $\begin{array}{l}\text { 7. Kendalanya mungkin untuk siswa yang } \\
\text { tidak rajin maupun tidak suka membaca } \\
\text { buku. Tapi ini akan membantu guru dalam } \\
\text { membimbing siswa dalam pembelajaran } \\
\text { matematika. }\end{array}$ \\
\hline
\end{tabular}

Sumber: diolah dari data penelitian

2. Design

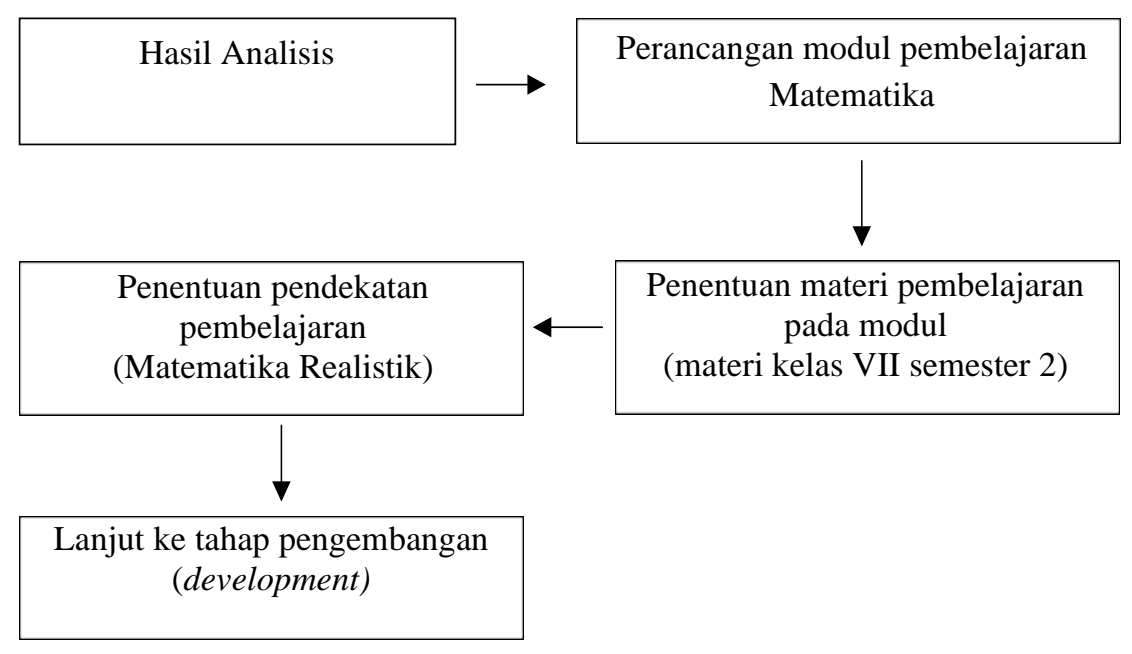

Gambar 2. Langkah Desain Modul 


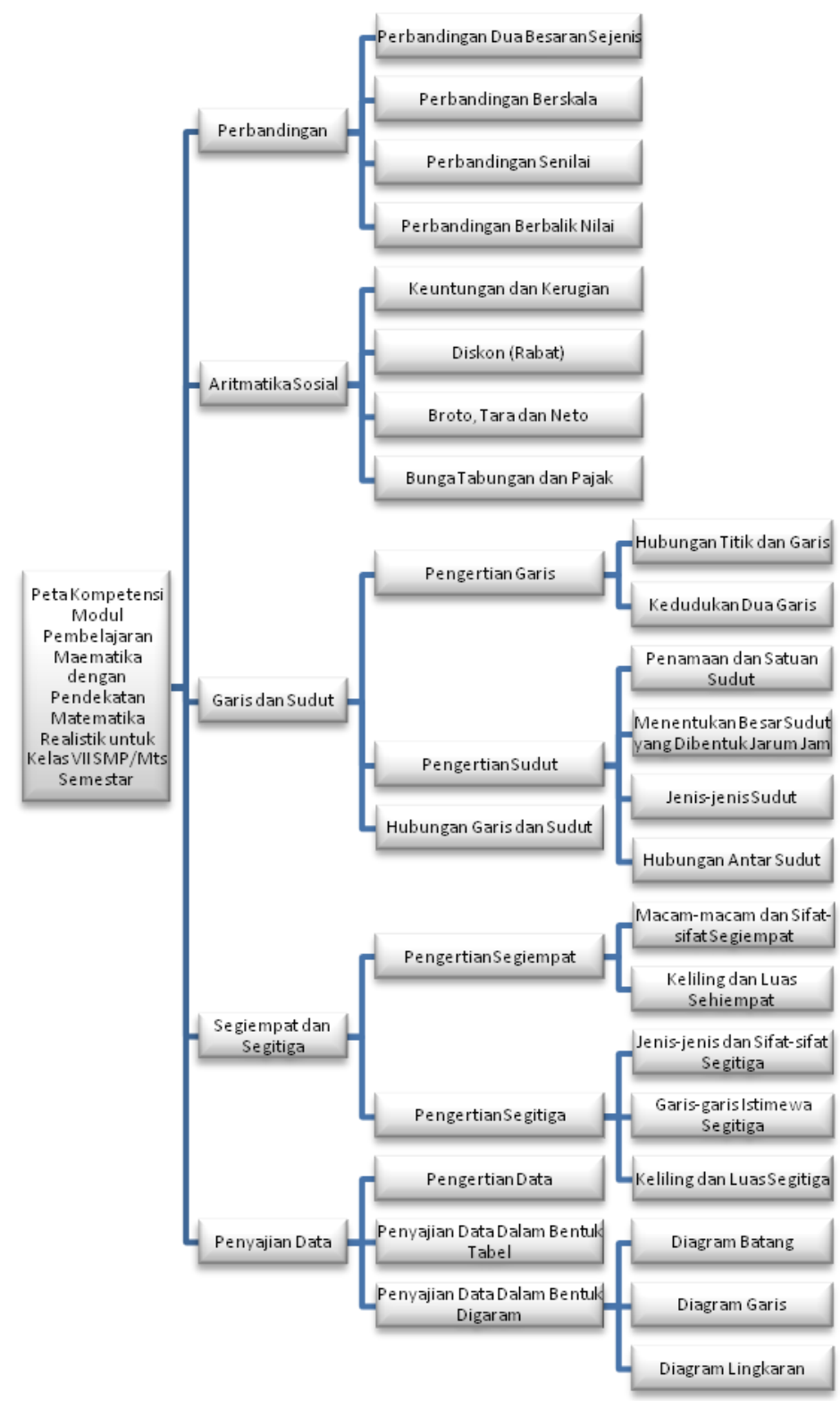

Gambar 3. Peta Kompetensi Modul Pembelajaran Matematika KelasVII Semester 2

3. Develop

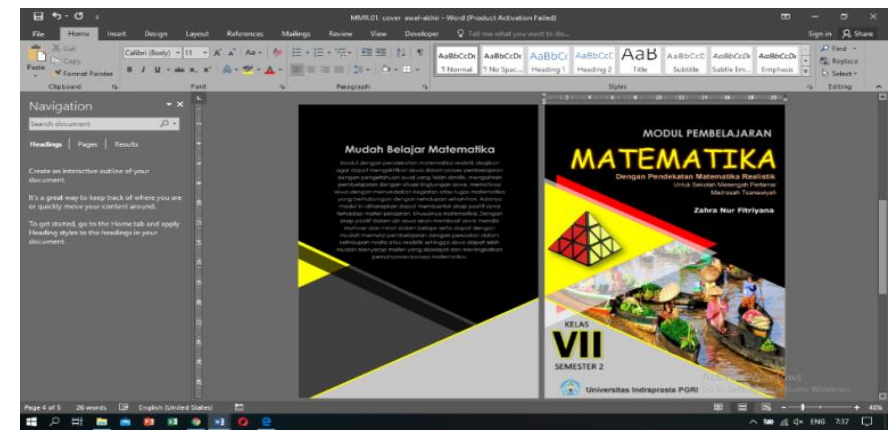

Gambar 4. Pembuatan Cover Modul 


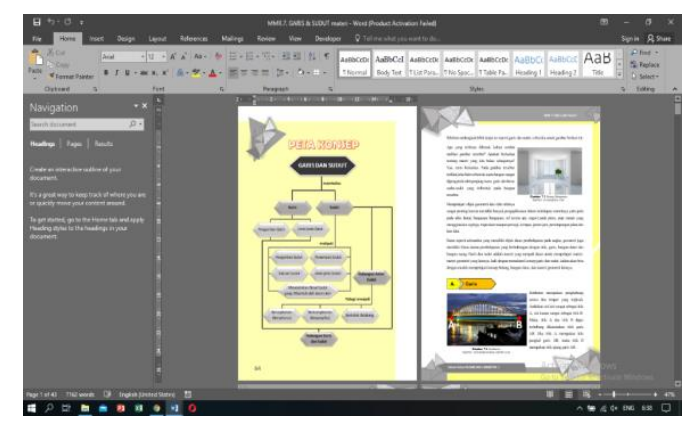

\section{Gambar 5. Pembuatan Peta Konsep dan Materi pada Modul}

\section{Implement}

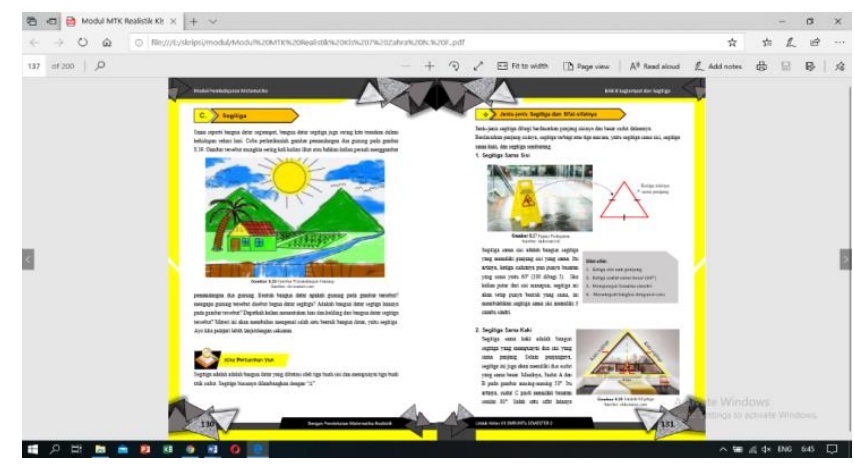

Gambar 6. Materi pada Modul

Penilaian kelayakan produk diuji dan dinilai oleh pakar yaitu ahli media, ahli materi, dan ahli bahasa. Penilaian dilakukan setelah produk media pembelajaran divalidasi terlebih dahulu. Menurut Sudijono (dalam Dasmo dkk, 2017:73) untuk mengetahui persentase rata-rata tiap komponen dihitung menggunakan rumus sebagai berikut:

$$
P=\frac{F}{N} \times 100 \%
$$

$F$ adalah skor yang didapat, $N$ adalah Number of cases (jumlah frekuensi/banyaknya individu), dan $P$ adalah angka persentase. Selanjutnya interval kriteria penilaian pakar dapat diperoleh melalui pengembangan. Tabel 2. merupakan kriteria kelayakan penilaian para pakar.

Tabel 2. Kriteria Kelayakan Media Pembelajaran

\begin{tabular}{cl}
\hline Skor Angket & \multicolumn{1}{c}{ Kriteria } \\
\hline $81 \% \leq$ skor $\leq 100 \%$ & Sangat Baik \\
$61 \% \leq$ skor $\leq 80 \%$ & Baik \\
$41 \% \leq$ skor $\leq 60 \%$ & Kurang Baik \\
$21 \% \leq$ skor $\leq 40 \%$ & Tidak Baik \\
Skor $<21 \%$ & Sangat Tidak Baik \\
\hline
\end{tabular}

Sumber: Arikunto (2009: 35) 
Tabel 3. Kisi-Kisi Instrumen Angket Penilaian Ahli Materi

\begin{tabular}{clcc}
\hline No & \multicolumn{1}{c}{ Aspek } & Jumlah Pertanyaan & N \\
\hline 1 & Kebahasaan & 3 butir & 12 \\
2 & Kesesuaian Materi & 9 butir & 36 \\
3 & Ilustrasi & 3 butir & 12 \\
\hline
\end{tabular}

$\mathrm{N}$ : Jumlah pertanyaan dikali dengan skor maksimum dalam skala likert

Tabel 4. Hasil Uji Pakar Oleh Ahli Materi

\begin{tabular}{lccc}
\hline \multicolumn{1}{c}{ Aspek Penilaian } & $\begin{array}{c}\text { Skor yang } \\
\text { Didapat }(f)\end{array}$ & Persentase & Kategori \\
\hline Aspek Kebahasaan & 12 & $100 \%$ & Sangat Baik \\
Aspek Kesesuaian Materi & 33 & $91,67 \%$ & Sangat Baik \\
Aspek Ilustrasi & 10 & $83,33 \%$ & Sangat Baik \\
$\quad$ Rata-rata & & $91,67 \%$ & Sangat Baik \\
\hline
\end{tabular}

Tabel 5. Kisi-Kisi Instrumen Angket Penilaian Ahli Media

\begin{tabular}{clcc}
\hline No & \multicolumn{1}{c}{ Aspek } & Jumlah Pertanyaan & N \\
\hline 1 & Tampilan Grafik & 10 butir & 40 \\
2 & Penyajian Materi & 4 butir & 16 \\
3 & Penggunaan & 3 butir & 12 \\
\hline
\end{tabular}

$\mathrm{N}$ : Jumlah pertanyaan dikali dengan skor maksimum dalam skala likert

Tabel 6. Hasil Uji Pakar Oleh Ahli Media

\begin{tabular}{lccc}
\hline \multicolumn{1}{c}{ Aspek Penilaian } & Skor yang Didapat $(f)$ & Persentase & Kategori \\
\hline Aspek Tampilan Grafik & 31 & $77,5 \%$ & Baik \\
Aspek Penyajian Materi & 14 & $87,5 \%$ & Sangat Baik \\
Aspek Penggunaan & 11 & $91,67 \%$ & Sangat Baik \\
$\quad$ Rata-rata & & $82,35 \%$ & Sangat Baik \\
\hline
\end{tabular}

Tabel 7. Kisi-Kisi Instrumen Angket Penilaian Ahli Bahasa

\begin{tabular}{clcc}
\hline & \multicolumn{1}{c}{ Aspek } & Jumlah Pertanyaan & N \\
\hline No & & 3 butir & 12 \\
2 & Lugas & 1 butir & 4 \\
3 & Komunikatif & 2 butir & 8 \\
4 & Kesesuaian dengan Perkembangan Siswa & 2 butr & 8 \\
\hline \multicolumn{3}{c}{ N : Jumlah pertanyaan Kaidah Bahasa } &
\end{tabular}


Tabel 8. Hasil Uji Pakar Oleh Ahli Bahasa

\begin{tabular}{lccc}
\hline \multicolumn{1}{c}{ Aspek Penilaian } & Skor yang Didapat $(f)$ & Persentase & Kategori \\
\hline Lugas & 9 & $75 \%$ & Baik \\
Komunikatif & 4 & $100 \%$ & Sangat Baik \\
Kesesuaian dengan & 10 & $87,5 \%$ & Sangat Baik \\
$\begin{array}{l}\text { Perkembangan Siswa } \\
\text { Kesesuaian dengan }\end{array}$ & & & Baik \\
$\begin{array}{l}\text { Kaidah Bahasa } \\
\quad \text { Rata-rata }\end{array}$ & 6 & $75 \%$ & Sangat Baik \\
\hline
\end{tabular}

\section{Evaluate}

Sumber: diolah dari data penelitian

Tahap terakhir adalah mengevaluasi modul pembelajaran yang telah diimplementasikan. Tahap ini dilakukan untuk perbaikan terhadap modul yang telah dikembangkan. Evaluasi yang penulis terima yaitu agar lebih memperhatikan penyusunan kalimat dan penulisan kalimat agar tidak ada kurang huruf (typo) serta terus meningkatkan variasi soal. Perbaikan ini dilakukan agar produk yang dikembangkan dapat memenuhi kebutuhan peserta didik serta dapat mencapai tujuan yang telah ditetapkan sebelumnya. Pada akhirnya, peneliti berharap produk ini dapat digunakan secara luas oleh siswa dan guru di seluruh Indonesia.

\section{PEMBAHASAN}

Produk yang telah diselesaikan adalah berupa modul pembelajaran matematika. Dick dan Carey (dalam Wena, 2011: 231) mengatakan bahwa modul sebagai unit pembelajaran berbentuk cetak, mengajar terpadu yang memiliki satu tema terpadu, menyajikan kepada siswa keterangan-keterangan yang diperlukan untuk menguasai dan menilai pengetahuan dan keterampilan yang ditentukan dan berfungsi sebagai satu komponen dari keseluruhan komponen dari keseluruhan kurikulum.Sedangkan pendekatan matematika realistik merupakan pendekatan yang menggunakan dunia real atau nyata untuk memulai suatu pembelajaran dengan cara mengajukan masalah. Jadi modul pembelajaran matematika dengan pendekatan matematika realistik ini dikembangkan agar siswa lebih dapat memahami pelajaran matematika lebih mudah dan mandiri. Berdasarkan analisi kebutuhan yang dilakukan sebelumnya didapat bahwa siswa terkadang sulit untuk membaca buku matematika, dimana guru lebih suka mengajar dengan cara ceramah dan menggunakan bahan ajar berupa buku paket saja. Di dalam modul ini dibuat materi dan soal - soal yang dikaitkan dengan kehidupan sehari - hari, sehingga siswa lebih mudah memahami konsep matematikanya. Seperti yang diungkapkan Sumarmo (dalam Rahayu dan Pujiastuti, 2018 : 96) mengatakan indikator - indikator pemahaman konsep yaitu, (1) menyatakan ulang sebuah konsep, (2) mengklasifikasi objek - objek menurut sifat - sifat tertentu (sesuai dengan konsepnya), (3) memberikan contoh dan non contoh dari konsep, (4) menyajikan konsep dalam berbagai bentuk representasi matematis, (5) mengembangkan syarat perlu atau syarat cukup suatu konsep, 6) menggunakan, memanfaatkan, dan memilih prosedur atau operasi tertentu, (7) mengaplikasikan konsep atau algoritma pemecahan masalah.

Berdasarkan hasil uji penilaian pakar yang telah dilakukan, dapat disimpulkan bahwa modul pembelajaran Matematika dengan pendekatan matematika realistik untuk siswa kelas VII semester genap ini layak untuk digunakan sebagai perangkat pendukung pembelajaran di sekolah yang dapat digunakan siswa dan dapat meningkatkan pemahaman konsep matematika siswa. Penetapan kriteria layak pada produk modul pembelajaran matematika dengan pendekatan matematika realistik untuk siswa kelas VII semester genap dilihat dari hasil data yang telah dinilai oleh para ahli yaitu untuk ahli materi mendapatkan skor nilai 91,67\% dengan kriteria sangat baik, ahli media mendapatkan skor nilai 82,35\% dengan kriteria 
sangat baik dan ahli Bahasa mendapatkan skor nilai 81,32\% dengan kriteria sangat baik. Maka di dapatkan hasil rata-rata untuk nilai validasi oleh ahli yaitu sebesar $85,11 \%$. Nilai rata-rata tersebut digolongkan sangat baik menurut ketentuan skala likert yang disajikan pada instrumen penilaian pakar. Respon yang didapat peneliti mengenai modul ini yaitu $83,32 \%$ dengan kriteria sangat baik.

Penilaian tersebut dilihat berdasarkan beberapa item pada aspek penilaian oleh para ahli. Berdasarkan penilaian ahli materi dalam aspek pernyataan pada item 1 mendapat skor 4 dengan persentase $100 \%$, hal ini menunjukkan bahwa kalimat yang digunakan dalam modul ini mudah dipahami dan terkategori sangat baik. Pada item 2 mengenai bahasa yang digunakan harus komunikatif mendapat nilai 4 dengan persentase $100 \%$, hal ini menunjukkan bahwa bahasa yang digunakan dalam modul ini komunitatis dan terkategori sangat baik. Item 3 yaitu mengenai kelengkapan informasi, dalam hal ini skor 4 dengan persentase 100\% menunjukkan bahwa kelengkapan informasi dalam modul ini sudah lengkap dan terkategori sangat baik. Item 4 mendapat skor 4 dengan persentase 100\%, hal ini menunjukkan bahwa dalam modul ini sudah terdapat materi yang berisikan konsep yang sesuai dengan fakta dan terkategori sangat baik. Pada item 5 mengenai isi materi dalam modul yang jelas dan padat mendapatkan skor 4 dengan persentase $100 \%$ yang berarti terkategori sangat baik, sehingga memudahkan dipelajari secara tuntas. Item 6 mendapat skor 4 dengan persentase 100\% dengan kategori sangat baik yaitu mengenai kesesuaian judul dengan materi. Item 7 mendapat skor 3 dengan persentase $75 \%$ yaitu mengenai kesesuaian materi dengan kompetensi yang berarti baik. Pada item 8 yaitu adanya contoh soal beserta pembahasan mendapat skor 4 dengan persentase 100\% dengan kategori sangat baik. Item 9 mengenai kejelasan dalam penulisan rumus Matematika mendapat skor 4 dengan persentase 100\%, hal ini menunjukan penulisan rumus dalam modul matematika sudah jelas dan terkategorikan sangat baik. Item 10 mendapat skor 3 dengan persentase $75 \%$ mengenai ketersediaannya soal yang variatif, dan terkategori baik. Item 11 yaitu menenai kesesuaian penyajian masalah dengan materi, mendapatkan skor 4 dengan persentase $100 \%$ dengan kategori sangat baik. Item 12 mendapat skor 3 dengan persentase $75 \%$ yaitu mengenai kesesuaian contoh fenomena Matematika dengan konsep Matematika. Item 13 mendapatkan skor 4 dengan persentase $100 \%$ yaitu mengenai gambar dan animasi yang sesuai dengan materi. Item 14 mengenai materi dan gambar yang disajikan secara sistematis, mendapatkan skor 3 dengan persentase $75 \%$, hal ini karena terdapat beberapa penyajian gambar dan materi yang kurang sistematis. Item 15 mendapatkan skor 3 dengan persentase $75 \%$ mengenai kesesuaian pertanyaan soal evaluasi dengan materi dan terkategori baik.

Berdasarkan penilaian ahli media dalam aspek pernyataan pada item 1 yaitu mengenai kesesuaian desain cover mendapat skor 4 dengan persentase $100 \%$ yang terkategorikan sangat baik. Item 2 mendapatkan skor 3 dengan persentase $75 \%$ dari $100 \%$ mengenai tata letak, hal ini dikarenakan dalam modul ini masih terdapat beberapa ruang kosong dan tata letaknya masih harus disesuaikan agar lebih menarik dan jelas. Item 3 mengenai kemenarikan penampilan isi materi, mendapatkan skor 3 dengan persentase $75 \%$ yang terkategorikan baik. Item 4 mengenai kejelasan gambar mendapatkan nilai 3 dengan persentase $75 \%$ yang terkategorikan baik. Item 5 sampai item 10 mengenai bentuk dan ukuran huruf yang mendapatkan skor 3 dengan persentase $75 \%$, hal ini karena masih terdapat beberapa bentuk dan ukuran huruf yang belum sesuai sehingga mengurangi daya tarik dan kemudahan dibaca namun tetap dengan kategori baik. Item 11 mengenai tampilan media, mendapatkan skor 4 dengan persentase 100\%, hal ini menunjukan penulisan maupun gambar yang menjadikan tampilan modul menarik dengan kategori sangat baik. Item 12 mengenai penyajian fenomena matematika dalam kehidupan sehari-hari mendapatkan skor 3 dengan persentase $75 \%$, karena ada beberapa penyajian dan gambar yang sudah biasa, sehingga kurang menarik. Item 13 mengenai konsep matematika dalam kehidupan sehari-hari mendapatkan skor 4 dengan persentase $100 \%$ dengan kategori sangat baik. Item 14 mengenai ilustrasi gambar yang menarik mendapatkan skor 3 dengan persentase $75 \%$, hal ini menunjukan ilustrasi gambar pada modul menarik dan 
terkategori baik. Pada item 15 mendapat skor 4 dengan persentase 100\% mengenai kemudahan modul untuk dibawa ternilai sangat baik. Item 16 yaitu mudah digunakan, mendapatkan skor 3 dengan persentase 75\% dengan kategori baik. Item 17 mendapatkan skor 4 dengan persentase $100 \%$ mengenai pemberian judul atau keterangan media dengan kategori sangat baik. Pemberian judul ini merupakan salah satu elemen mutu modul pada bagian organisasi yang penting untuk memudahkan siswa dalam membaca dan mempelajari secara mandiri.

Berdasarkan penilaian ahli bahasa dalam aspek pernyataan pada item 1 yaitu mengenai ketepatan struktur kalimat mendapatkan skor 3 dengan persentase 75\% dengan kategori baik. Item 2 mengenai keefektifan kalimat mendapat skor 3 dengan persentase $75 \%$, hal ini karena ada beberapa kalimat dalam modul yang kurang efektif namun tetap terkategorikan baik. Kebakuan istilah terdapat pada item 3 dengan skor 3 dengan persentase $75 \%$, hal ini karena ada beberapa kata dalam penyajian masalah dalam modul yang menggunakan kata tidak baku. Pada item 4 mendapatkan skor 4 dengan persentase $100 \%$ mengenai pemahaman terhadap pesan atau informasi yang disampaikan dalam modul dan terkategorikan sangat baik. Item 5 mendapatkan skor 3 dengan persentase $75 \%$, yaitu mengenai kesesuaian dengan tingkat perkembangan emosional siswa. Pada item 6 mendapatkan skor 4 dengan persentase 100\% mengenai kesesuaian dengan tingkat perkembangan emosional siswa. Pada item 7 dan 8 yaitu mengenai ketepatan tata bahasa dan ejaan, mendapatkan skor 3 dengan persentase $75 \%$, hal ini dilihat dari beberapa kalimat dalam modul yang masih belum menggunakan tanda baca seru (!) dalam setiap kalimat perintah maupun kalimat seru lainnya serta masih ada beberapa penulisan paragraf yang belum sesuai dengan aturan penulisan dalam kaidah bahasa Indonesia yang baik dan benar.

Pembuatan modul pembelajaran matematika ini dilakukan peneliti mengingat pentingnya media pembelajaran yang sesuai dengan kurikulum 2013 yang berlaku saat ini. Selain itu, mata pelajaran matematika memang membutuhkan penalaran yang dapat disesuaikan dalam kehidupan sehari-hari. Berdasarkan hal tersebut, peneliti mengembangkan modul pembelajaran matematika dengan pendekatan matematika realistik yang efektif digunakan untuk meningkatkan pemahaman konsep matematika siswa, hal ini sejalan dengan penelitian yang dilakukan oleh Ramdani (2014) menunjukkan bahwa bahan ajar dengan pendekatan PMRI yang dikembangkan dapat memudahkan siswa memulai pembelajaran dengan persoalan dalam kehidupan nyata atau realistik sehingga siswa dapat lebih mudah menyerap materi yang dipelajari dan meningkatkan pemahaman konsep matematika siswa, hal tersebut menunjukan bahwa bahan ajar tersebut efektif digunakan untuk memfasilitasi pencapaian literasi matematika siswa dibandingkan dengan bahan ajar yang bersifat konvensional. Hal ini sejalan dengan penelitian yang dilakukan Ikhsan (2012) menunjukan bahwa bahan ajar yang dikembangkan berupa buku siswa dengan pendekatan PMRI memenuhi kriteria baik dilihat dari keseluruhan komponen kelayakan isi, komponen kebahasaan, komponen penyajian dan komponen kegrafikan, sehingga sesuai dengan hasil tes keterbacaan dan menunjukan bahwa buku siswa mudah dimengerti oleh siswa.

Modul pembelajaran matematika ini diharapkan dapat membantu guru dalam kegiatan pembelajaran, khususnya guru matematika kelas VII di SMP Negeri 90 Jakarta. Peneliti juga berharap modul ini diharapkan dapat meningkatkan pemahaman konsep matematika dan minat siswa untuk belajar matematika dengan menggunakan modul pembelajaran ini khususnya untuk siswa kelas VII SMP Negeri 90 Jakarta, sehingga, kegiatan pembelajaran dapat berjalan dengan efektif dan siswa dapat secara mandiri mempelajari materi dan mengerjakan latihan soal melalui modul pembelajaran ini. Melalui modul pembelajaran ini siswa akan dilatih keterampilan bernalarnya dalam meningkatkan kemampuan berpikir matematika agar menjadi pribadi yang bermanfaat yang dapat menyelesaikan berbagai masalah di dunia nyata secara ilmiah. 


\section{SIMPULAN}

Berdasarkan hasil penelitian dan pembahasan, maka dapat disimpulkan Desain pengembangan modul pembelajaran matematika dengan pendekatan matematika realistic untuk siswa SMP/MTs kelas VII semester genap modul pembelajaran matematika dibuat dengan pendekatan matematika realistik yang didasarkan pada penelitian pengembangan (Research and Development) dengan model pengembangan ADDIE (Analysis, Design, Development, Implementation dan Evaluation) yang merupakan model desain pembelajaran berlandaskan pada pendekatan sistem yang bersifat interaktif. Berdasarkan hasil uji validasi oleh ahli materi didapatkan hasil skor rata-rata 91,67\%. Hasil uji validasi oleh ahli media didapatkan hasil skor rata-rata $82,35 \%$. Hasil uji validasi oleh ahli bahasa didapatkan hasil skor rata-rata 81,32\%. Ketiga hasil skor rata-rata oleh ahli media, materi dan Bahasa tergolong dalam kriteria "sangat baik" dengan kata lain media ini menurut para ahli layak untuk digunakan dan diujikan kepada siswa. Sehingga dapat disimpulkan bahwa modul pembelajaran matematika dengan pendekatan matematika realistic untuk siswa kelas VII SMP/MTs semester genap ini layak untuk digunakan sebagai perangkat pendukung pembelajaran di sekolah.

\section{DAFTAR RUJUKAN}

Arikunto, S., Safruddin, A. J., dan Cepi. (2009). Evaluasi Program Pendidikan. Jakarta: Bumi aksara.

Dasmo, D., Astuti, I. A. D., dan Murullaeli, N. (2017). Pengembangan Pocket Mobile Learning Berbasis Android. Jurnal Riset dan Kajian Pendidikan Fisika, 4(2), 22-28.

Erman, S. (2003). Strategi Pembelajaran Matematika Kontemporer. Bandung: Universitas Pendidikan Indonesia.

Ikhsan. (2012). Pengembangan Bahan Ajar Matematika Pada Topik Aljabar dengan Pendekatan PMRI untuk siswa Kelas VIII SMP/MTs. Skripsi: Universitas Negeri Yogyakarta.

Murdani, Johar, R., \& Turmudi. (2013). Pengembangan Perangkat Pembelajaran Matematika dengan Pendekatan Realistik untuk Meningkatkan Penalaran Geometri Spasial Siswa di SMP Negeri Arun Lhokseumawe. Jurnal Peluang, 1(2), 22-32. Retrieved from: http://jurnal.unsyiah.ac.id/peluang/article/view/1054/990

Mulyono, A.(2003). Pendidikan Bagi Anak Berkesulitan Belajar. Jakarta: Rineka Cipta.

Nasution, S.(2005). Berbagai Pendekatan Dalam Proses Belajar dan Mengajar. Jakarta: PT. Bumi Aksara.

Nasution, S.(2010). Berbagai Pendekatan Proses Belajar dan Mengajar. Jakarta: Bumi Aksara.

Prastowo, A.(2013). Panduan Kreatif Membuat Bahan Ajar Inovatif. Jogjakarta. DIVA Press.

Rahayu, Y., dan Pujiastuti, H. (2018). Analisis Kemampuan Pemahaman Matematis Siswa SMP pada Materi Himpunan: Studi Kasus di SMP Negeri 1 Cibadak. Pasundan Journal of Research in Mathematics Learning and Education, 3(2), 93-102.

Ramdani, I. (2014). Pengembangan bahan ajar dengan pendekatan pendidikan matematika realistic indonesia (PMRI) untuk memfasilitasi pencapaian literasi matematika siswa kelas VII. Skripsi: Universitas Negeri Yogyakarta.

Soviawati, E. (2011). Pendekatan Matematika Realistik untuk Meningkatkan Kemampuan Berfikir Siswa di Tingkat Sekolah Dasar. Metodik Didaktik : Jurnal Pendidikan Ke-SD-an, Edisi Khusus No. 2, 7985. 
Tegeh, I. M., \& Sukmana, A. I. W. I. Y. (2018). Pengembangan Media Strip Comic dengan Model ADDIE pada Mata Pelajaran IPA untuk Meningkatkan Motivasi Belajar Siswa Kelas V di SD Negeri 1 Sari Mekar. Jurnal Edutech Undiksha, 6(2), 245-255.

Wena, M. (2011). Strategi Pembelajaran Inovatif Kontemporer. Jakarta: Bumi Aksara. 
292 Fitriyana, Mailizar, \& Seruni

JKPM (Jurnal Kajian Pendidikan Matematika) Vol.6, No.2 (2021) 